\title{
Conflict Management and Age on Service Professions
}

DOI:

10.1108/IJCMA-10-2015-0070

10.1108/IJCMA-10-2015-0070

10.1108/ijcma-10-2015-0070

Document Version

Accepted author manuscript

Link to publication record in Manchester Research Explorer

\section{Citation for published version (APA):}

Beitler, L. A., Machowski, S., Johnson, S., \& Zapf, D. (2016). Conflict Management and Age on Service Professions. International Journal of Conflict Management, 27(3), 302-330. https://doi.org/10.1108/IJCMA-102015-0070, https://doi.org/10.1108/IJCMA-10-2015-0070, https://doi.org/10.1108/ijcma-10-2015-0070

\section{Published in:}

International Journal of Conflict Management

\section{Citing this paper}

Please note that where the full-text provided on Manchester Research Explorer is the Author Accepted Manuscript or Proof version this may differ from the final Published version. If citing, it is advised that you check and use the publisher's definitive version.

\section{General rights}

Copyright and moral rights for the publications made accessible in the Research Explorer are retained by the authors and/or other copyright owners and it is a condition of accessing publications that users recognise and abide by the legal requirements associated with these rights.

\section{Takedown policy}

If you believe that this document breaches copyright please refer to the University of Manchester's Takedown Procedures [http://man.ac.uk/04Y6Bo] or contact uml.scholarlycommunications@manchester.ac.uk providing relevant details, so we can investigate your claim.

\section{OPEN ACCESS}




\section{Emerald International Journal}

\section{Conflict Management and Age in Service Professions}

\begin{tabular}{|r|l|}
\hline Journal: & International Journal of Conflict Management \\
\hline Manuscript ID & IJCMA-10-2015-0070.R1 \\
\hline Manuscript Type: & Research Paper \\
\hline Keywords: & conflict management, age, burnout, service work, customer stressors \\
\hline \multicolumn{2}{|c}{} \\
\hline
\end{tabular}

SCHOLARONE $^{\text {m }}$

Manuscripts 


\begin{abstract}
Purpose - The purpose of this study was to examine age differences in conflict management strategy use, effectiveness, and in exposure to customer stressors in service interactions.

Design/methodology/approach - Moderated regression and mediation analyses were conducted to test hypotheses in a sample of 444 German service employees from different service branches with frequent customer contact.
\end{abstract}

Findings - Results revealed that older service employees experienced fewer customer stressors. Customer stressors mediated the negative relationship between age and burnout. Age was associated with use of passive avoidant (avoiding) and active constructive (eempromising, problem solving) conflict management strategies. Furthermore, older employees used those strategies more effectively. Especially when avoiding conflicts, older employees reported more professional efficacy than younger colleagues. In contrast, younger employees benefited considerably less from strategy use and reported higher levels of burnout in general. Thus, results suggest older employees' effective conflict management and their positive perception of customer stressors contribute to lower levels of burnout.

Practical implications - Results speak against a general deficit model for older workers as they show specific strengths of older employees in social conflicts. TheirOlder service employees' expertise in dealing with negative social interactions represents an important resource for organizations and training interventions, such as mentoring programs.

Originality/value - This study is one of the first to examine age-related conflict management skills with regard to customer conflicts, employee health, and effectiveness of strategy use. It replicates existing findings on age and conflict management and extendts them in several ways thereby ruling out alternative explanations for age effects.

Keywords: Conflict management, age, burnout, service work, customer stressors 
Conflict is inevitable in any social life domain and a common experience at the workplace. Service employees with frequent customer contact deal with elevated levels of social conflicts (Bitner et al., 1994; Dormann and Zapf, 2004; Grandey et al., 2002) and therefore require distinct socio-emotionalsocioemotional competencesqualifications, such as appropriate conflict management strategies, in order to successfully manage demanding customer interactions. While demographic change has caused increasing dependency on competent older workers, research on age and secio-emotionalsocioemotional competences at work is scarce (exceptions being, e.g., Dahling and Perez, 2010; Johnson et al., 2013; Yeung and Fung, 2012). Although there is an increasing body of research outside the work domain showing that older individuals cope more successfully with negative social interactions than younger people (e.g., Blanchard-Fields, 2007; Blanchard-Fields et al., 2007; Diehl et al., 1996), there is hardly any-little organizational research on this issue. To the best of our knowledge, there are only two studies explicitly dealing with age and conflict management at work (i.e., Davis et al., 2009; Yeung et al., 2015). Both demonstrate that older workers use more passive conflict management strategies (such as avoiding or yielding) than younger ones. However, these studies focused on managers and their strategy use in conflicts with colleagues (supervisors, peers, and subordinates; Davis et al., 2009; Yeung et al., 2015). They did not take customers as potential conflict partners in service professions into account. However, service industry constitutes the largest proportion (about 70\%) of the European labor market (European Commission, 2015) and characteristics of the service situation may influence the choice of conflict management strategies. Service employees spend more time interacting with customers than with their colleagues (Dormann and Zapf, 2004) and face elevated levels of customer conflict (Bitner et al., 1994; Grandey et al., 2002), which can result in burnout (Ben-Zur and Yagil, 2005; De Dreu et al., 2004). Thus, it is relevant to address this research gap by examining age-related differences in conflict management skills 
of service employees. Furthermore, previous studies found that older people are less susceptible to burnout (e.g. Brewer and Shapard, 2004). With regard to service jobs, lower burnout levels could indicate a more effective management of negative customer interactions. Therefore, this study aims to explain differences in the-exposure to negative customer behaviors, in the use and effectiveness of conflict management strategies, and differences in burnout from an age perspective. It replicates some of the findings by Yeung et al. (2015) and Davis et al. (2009) and extends them with regard to conflict partner, branch, culture, and outcome variable.

\section{Customer Stressors, Burnout, and Age}

Service employees with frequent customer interactions are often confronted with inappropriate customer behaviors and attitudes, known as customer stressors (Dormann and Zapf, 2004; Grandey et al, 2004; 2007). Dormann and Zapf (2004) classified four different customer stressors in the service sector. Disproportionate customer expectations refer to customers' behaviors and attitudes, which challenge acceptable service expectations from the service employee's point of view. Verbally aggressive customers criticize and verbally attack service employees. Disliked customers refer to unpleasant, humorless and hostile customers. When being confronted with ambiguous customer expectations, it is unclear to the service employee what the customer wants. Such-It has repeatedly been shown that customer stressors are detrimental to the and affect-well-being of service employees (see below).more than other daily stress events (Bolger et al., 1989). Thus, the examination of age differences regarding exposure to customer stressors is important, but research is scarce. In one of the few studies, Johnson et al. (2013) showed that older service employees are less likely to experience customer stressors. Research in the field of daily hassles supports this and suggests that as 
people age they perceive interpersonal tensions as less negative or stressful (Luong et al., 2011) and rate conflict situations more positively than younger individuals (Diehl et al., 1996). Thus, there is a cognitive positivity bias on conflict perception with increased age (Charles et al., 2003). These findings indicate that the appraisal of, and reaction to, social stressors, underlie age-related improvements in secio-emotionalsocioemotional competencies. This notion is in accordance with socioemotional selectivity theory (SST; e.g., Carstensen et al., 1999) which describes an age-related adaptation to diminished future prospects by enhancing one's attention to positive rather than negative emotional aspects of life with advanced age. Thus, older service employees may report less customer stressors because they contribute less to conflicts and they see potential conflict situations with customers as less threatening. Therefore, it is proposed:

\section{Hypothesis 1: There is a negative relationship between age and the exposure to customer} stressors.

Being confronted with frequent customer stressors is demanding and can impair employee health in terms of burnout (e.g., Ben-Zur and Yagil, 2005; Dormann and Zapf, 2004; Kern and Grandey, 2009; Dudenhöffer and Dormann, 2015; Grandey et al., 2004). Explanations for these health implications can be partly found in situational issues regarding the imbalance and restrictions of employee-customer-relations. For example, customer interactions are lowcontrol situations, in which service employees have little impact on customer behaviors and are restricted by organizational demands. Customer orientation and a friendly service mentality need to be maintained, even when being treated disrespectfully (Zapf, 2002). Thus, $\underline{\text { service employees need to exert self-control (e.g., hiding negative emotions, keeping up }}$ $\underline{\text { motivation to serve unpleasant customers) which can deplete ones resources and finally lead }}$ to burnout (Baumeister et al., 2000; Schmidt et al., 2007). 
$\underline{\text { A }}$ Mmeta-analysis by Brewer and Shapard (2004) on the relationship between age and

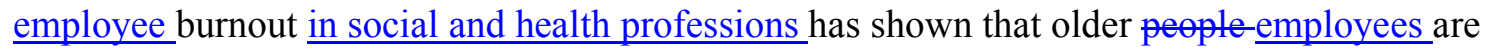
less susceptible to emotional exhaustion than younger people employees(e.g. Brewer and Shapard, 2004). Dormann and Zapf (2004) Studies-investigateding flight attendants, travel agency employees, and sales clerks employees in the service industry and also found a negative relation between age and burnoutcorrespond with these findings (e.g. Dormann and Zapf, 2004). On this basis, a negative correlation between age and service employee burnout is proposed. However, Oone aim of the present study is to contribute to a wider understanding of age-related decreases in burnout in the context of customer conflicts and , thereby-therefore addressing investigates two possible reasonsexplanations for these decreases. One-The first possible explanation is, when individuals grow older they experience fewer customer stressors and experience-more pleasant service interactions due to a more positive perception (see Hypothesis 1). As a consequence, there are fewer self-control demands for older service employees (Schmidt et al., 2007). Additionally, Ppositive experiences with customers can represent a significant resource for service employees in coping with customer stressors (Dormann and Zapf, 2004) and thus, may prevent depletion of resources and explain lower

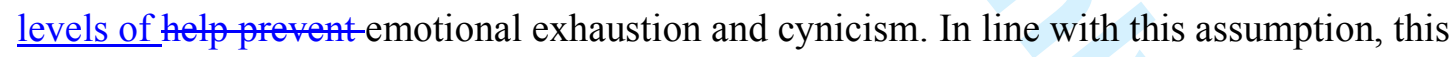
study predicts the negative relation between age and both emotional exhaustion and cynicism will be mediated by the frequency of experienced customer stressors. It is unlikely that the mere absence of a social stressor increases feelings of professional efficacy. Therefore, only emotional exhaustion and cynicism are taken into account. Furthermore, it is unlikely that the negative relation between age and burnout can be fully explained by lower levels of customer $\underline{\text { stressors, since multiple factors can be responsible for decreases in burnout with age. For }}$ example, older people manage stress more effectively (Johnson et al., 2013), they have more positive job attitudes, such as job satisfaction, and they experience different work 
environments than younger employees (e.g., less role conflict or role ambiguity; $\mathrm{Ng}$ and Feldman, 2010). Therefore, partial rather than full mediation is expected.

\section{Hypothesis 2: Customer stressors partially mediate the relationship between age and both emotional exhaustion and cynicism.}

A The second possible reason-explanation for age-related decreases in burnout being addressed in this paper is the development of effective conflict management strategies based on life experience with social stressors. This will be addressed in the following.

\section{Conflict Management in Service Interactions}

Interpersonal conflicts can be defined as real or perceived incompatibilities of interests, goals or needs (Taylor and Moghaddam, 1994)and, often occurring when there is disagreement between interdependent parties (Barki and Hartwick, 2004). In terms of service interactions, $\underline{\text { the customer's perception of a service employee negatively affecting something that matters }}$ to the customer, or vice versa, may lead to conflict (Thomas, 1992). Conflicts are threatening for most people (De Dreu and Van Knippenberg, 2005), since they can affect one's positive view of self (Chen et al., 2013), especially when the impact on the conflict partner's behavior is limited due to service demands. However, whether or not conflicts have positive or negative consequences depends on how conflicts are managed (Dijkstra et al., 2009).

Research on conflict management converges on the Dual Concern Theory by Pruitt and Rubin (1986; Davis et al., 2004) who describe five different conflict management strategies as a functions of concern for self and concern for others (De Dreu et al., 2001; Van de Vliert, 1997). Avoiding conflicts (low self and other concern) implies lowering the personal importance of the issue and avoiding a confrontation with the conflict partner in order to 
prevent conflict escalation. Yielding (low self and high other concern) is manifested by accommodating the conflict partner and adapting to the others will by making by nonreciprocal concessions. Compromising (intermediate self and other concern) involves the search for a solution by matching the aspirations of each conflict party. This implies that both parties have to distance themselves from their own point of view in order to find a compromise. Problem solving (high self and other concern) involves finding a solution satisfying to both conflict parties. In order to achieve a win-win-solution, the conflict issue needs to be considered by both parties and both must develop trust in each other and show willingness to collaborate. Forcing (high self and low other concern) includes the imposition of one's own will, persuasion, and threats. Thus, striving for personal gains is a central aspect of this conflict approach (De Dreu et al. 2001; Pruitt and Rubin, 1986).

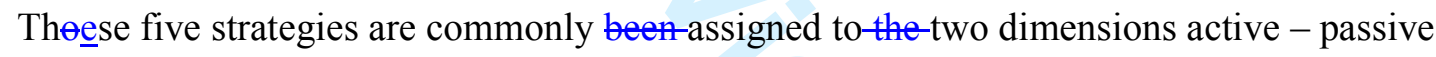
(strategies-confronting vs. .r avoiding the problem) and destructive - constructive (strategies benefitting er $\underline{v s .}$ harming a relationship) (c.f. Birditt et al., 2005; Birditt and Fingerman, 2005; Davis et al., 2004, 2009). Active constructive strategies encompass actions that directly tackle the problem and in best case lead to a solution, such as problem solving and compromising. Active destructive strategies refer to actions to fight in order to win at all costs, such as forcing. Yielding and avoiding confrontations can be referred to as passive avoidant strategies, since they imply the intrapsychological regulation of one's emotional response to the conflict situation. Conflict behavior is described as effective when it reduces the conflict issue and the potential of conflict escalation and/or enhances the relationship with the conflict partner (Davis et al., 2004; Thomas, 1992). This implies there is no 'best' conflict management strategy, but that several strategies may lead to conflict de-escalation depending on other influential factors (e.g., situational context, individual differences, and conflict partner; Davis et al., 2009; Nguyen and Yang, 2012; Yeung et al., 2015). 
In general, passive avoidant and active destructive conflict strategies have been shown to be less effective than active problem-focused strategies and to be associated with exhaustion (e.g., Dijkstra et al., 2009; Gross and Guerrero, 2000) and reduced psychological well-being (De Dreu et al., 2004). However, if the characteristics of the conflict situation are taken into account, passive approaches, such as avoidance can also be an adequate conflict response. Regarding service professions, situational restrictions due to the implicit disequilibrium of power in customer interactions can impact the application of conflict management strategies. Under these circumstances, effective conflict management in the service context is likely to be realized by a deescalating approach, such as avoiding conflicts, giving in to the customer, searching for a compromise, or solving the problem, whereas attempts to impose one's own will on the customer by forcing will likely lead to a deterioration of the customer-employeerelationship. Thus, active destructive strategies may escalate conflict in service interactions, while active constructive and passive avoidant conflict responses can be helpful in successfully managing customer stressors and may enable service employees to provide a customer-oriented service.

\section{Conflict Management and Age}

Individual conflict management skills develop over the life span. SST (Carstensen et al., 1999) suggests age differences in interpersonal conflict behavior (Davis et al., 2009) and proposes that with increased age individuals regulate their social interaction by enhancing attention to positive emotional aspects in order to preserve their wellbeing. Intensifying existing relationships, striving for emotional satisfaction, and maximizing social and emotional gains rise in meaning as people grow older. At the same timeMeanwhile, older people dissociate themselves from annoying and irritating relationships, thereby minimizing 
social and emotional risks (Carstensen et al., 1999). Thus, according to SST, older people are less likely to engage in destructive conflict behaviors, which potentially harm relationships and lead to conflict escalation. In contrast, with increased age, individuals are more likely to apply passive avoidant and active constructive conflict strategies in order to identify solutions, prevent conflict escalation, and regain emotional comfort (Birditt and Fingerman, 2005; Carstensen et al., 1999; Davis et al., 2009). This theoretical notion finds support by several empirical studies from outside the work domain showing that with increased age individuals prefer non-confrontational conflict strategies in order to minimize negative experiences (Blanchard-Fields et al., 2007; Blanchard-Fields et al., 2004; Birditt and Fingerman, 2005; Birditt et al., 2005). Yeung et al.'s (2015) study on age and workplace conflict underpins these findings. They investigated younger (40 years and below) and older (41 years and above) employees in China with regard to their conflict responses towards different conflict partners (supervisors, peers, and subordinates). Older compared to younger employees used more avoiding when managing conflicts with supervisors than when managing conflicts with subordinates. Moreover, Davis et al. (2009) showed that supervisors, peers, and subordinates rated older employees to be more likely to engage in passive avoidant conflict responses (such as adapting, letting matters settle down, yielding, etc.). Given that this previous research focused on age and conflicts with supervisors, peers, and subordinates, it remains unclear whether there are age differences in service employees' use of conflict management strategies

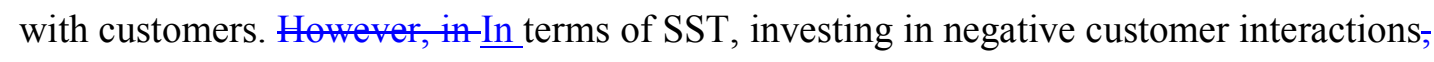
which are temporary (Bitner et al., 1994) and mostly peripheral relationships, may be $\underline{\text { is }}$ neither desirable nor expedient for older service employees (Luong et al., 2011), since customer interactions are temporary (Bitner et al., 1994) and mostly peripheral relationships. Thus, older employees are well aware of their limited psychological resources in service 
situations and they may choose the target of their psychological investment more carefully by avoiding confrontations with customers and/or giving in to the customer's opinion.

\section{Hypothesis 3a: There is a positive relation between age and the use of passive avoidant conflict management strategies, such as yielding and avoiding the conflict with customers.}

Older people have a large strategy repertoire and use a variety of different strategies in order to manage conflict (Blanchard-Fields, 2007; Blanchard-Fields et al., 2007; Watson and Blanchard-Fields, 1998). They not only apply passive strategies but also show active constructive conflict responses (Balay, 2007; Bergstrom and Nussbaum, 1996; Balay, 2007). Even though older adults choose more avoidant-denial strategies when facing interpersonal problems, they also report using more active strategies relating to the problem, when being confronted with instrumental issues (Blanchard-Fields et al., 2007). Considering service jobs, customer conflicts may sometimes require an active approach to the problem. With regard to workplace conflict, Davis et al.'s (2009) study showed older employees to be more likely to be rated as responding with active constructive strategies in conflicts with supervisors and peers than their younger colleagues. An increase in active constructive conflict responses with age can be explained on the basis of gains in wisdom, which mainly take place between middle (41-58 years) and old (60-90 years) adulthood (Grossmann et al., 2010). Wisdom is defined as "a complex and dynamic system of exceptional knowledge (expertise) in the fundamental pragmatics of life" (Baltes and Smith, 2008, p. 58) and is useful in order to handle problems of social life. Older individuals possess more knowledge about differences in values, goals, and priorities, show more social sensitivity and perspective taking (Baltes et al., 1995), and reach the highest scores on wisdom dimensions, such as perspective shifting and search for compromise (Grossmann et al., 2010). Higher acceptance of, and tolerance for, customers' perspectives are important preconditions in order to compromise and solve a 
problem. Thus, it is assumed that older service employees will more likely use active constructive conflict strategies compared to younger colleagues.

\section{Hypothesis 3b: There is a positive relation between age and the use of active constructive conflict management strategies, such as compromising and problem solving.}

\section{Effectiveness of Conflict Strategy Use and Age}

The use of conflict management strategies does not necessarily imply that strategies are being applied successfully. In order to examine the effectiveness of strategy use this study considers burnout with its three dimensions for two reasons. First, it is assumed that the more positively a conflict management strategy is related to health the more successful the strategy has been used. Second, professional efficacy is a valid predictor of performance (Gupta et al., 2013; Sitzmann and Yeo, 2013; Stajkovic and Luthans, 1998). Thus, successful conflict management should be positively related to professional efficacy.

There is evidence that individual coping strategies affect burnout. For example, a current meta-analysis by Shin et al. (2014) indicates problem-focused coping strategies (such as active and directive strategies) are negatively, and emotion-focused coping strategies (such as avoidance and disengagement) are positively related to burnout. Furthermore, Dijkstra et al. (2009) found conflicts to lead to exhaustion and psychological strain when passive conflict management strategies (conflict avoidance and yielding) were applied. However, individual characteristics, such as age (Shin et al., 2014; Blanchard-Fields et al., 2004) and differences in socio-emotionalsocioemotional motivations can influence the effect of strategy use on health.

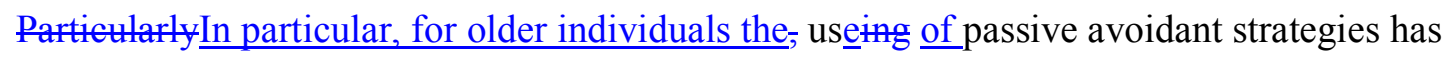

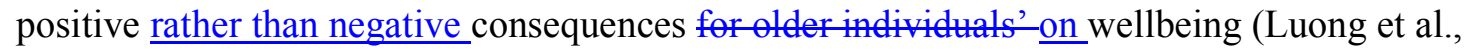


2011), instead of fostering burnout. For example, older people show reduced levels of affective reactivity when avoiding conflicts (Charles et al., 2009; Birditt, 2014) and lower intensity of negative emotions when suppressing emotions at work (Yeung and Fung, 2012). They can effectively apply passive coping strategies in order to lower emotional stress (Blanchard-Fields, 2007). Yeung at al. (2015) demonstrated that the negative effect of passive strategies on interpersonal relations at work was only shown for younger but and not for-older employees. These findings correspond with predictions of SST (Carstensen et al., 1999), i.e. older people prefer minimizing socio-emotionalsocioemotional risks in order to preserve their wellbeing. Thus, avoiding conflicts may be beneficial for older peoples' health. In contrast, the use of active destructive strategies may conflict with their secio-emotionalsocioemotional preferences and could have negative health effects for older individuals.

Several studies indicate older employees suffer less from burnout compared to younger colleagues (Brewer and Shapard, 2004). In addition to fewer customer stressors, ene-another explanation for this is, older workers have greater experience of interpersonal conflicts and conflict strategies which fosters effective conflict management-of conflicts. Older individuals have a larger strategy repertoire compared to younger people (Blanchard-Field et al., 2004). They show more sensitivity to the context (Blanchard-Fields et al., 1995) by choosing adaptive and complex conflict approaches (Blanchard-Fields et al., 2007; Grossmann et al., 2010) and therefore should be more effective in the use of conflict management strategies. Johnson et al. (2013) revealed older service employees to be more successful than younger ones in using stress management strategies (emotion control and active coping) to reduce emotional exhaustion and cynicism when facing high customer stressors. We suggest that this also applies for conflict management strategies. More successful handling of customer conflicts should result in conflict de-escalation, and in friendly service and customer satisfaction. This can be a valuable resource for older service employees (Dormann and Zapf, 
2004) leading to increased feelings of professional efficacy and lower levels of emotional exhaustion and cynicism due to less depletion of resources. Thus, age will moderate the relationship between conflict management strategies and burnout.

Hypothesis 4: Age moderates the relationship between the use of conflict management strategies and burnout. The negative relationship between passive avoidant/active constructive strategies and burnout will be stronger for older employees. The positive relationship between the active destructive strategy and burnout will be stronger for older employees.

\begin{abstract}
Method
Participants

Participants were service employees from different service branches in Germany (e.g., bank, insurance, consulting, restaurants, retail, handcraft, personnel service, tourism, logistics, pharmaceutical industry, car rental, IT, and industry). The aim was to collect a sample of the service industry, which is heterogeneous both with regard to service jobs and age. Participants were required to have frequent direct customer contact, so that negative customer interactions and conflicts were likely to occur. Recruitment took place by directly addressing-contacting supervisors or branch managers of potential organizations and stores. Participation was voluntary and questionnaires were allowed to be completed during work time. Anonymity and confidential handling of data was assured.
\end{abstract}

Data collection took place in the metropolitan areas of Germany between 2009 and 2010. In total 1028 questionnaires were distributed and 444 questionnaires returned (43.2\% response rate). None of the variables had more than $6 \%$ missings data with the exception of work age 
which had 33 missings. These missing data were considered to be at random and multiple data imputation to estimate missing values was applied (Little and Rubin, 2002). Participant age ranged from 16 to 70 years with a mean age of 40.63 years $(\mathrm{SD}=12.17)_{2} ; 61.9 \%$ participants were female and $65.1 \%$ had a fulltime job. This was representative of organizational demographics. On average, participants had been working in their current position for 8.95 years $(\mathrm{SD}=8.58$, range $0-40$ years $)$ and $40.3 \%$ worked in the retail sector.

\section{Measures}

Each scale had to be answered on a five-point Likert scale. In order to test internal consistency, Guttman's lambda2 ( $\lambda 2)$ was computed. Compared to Cronbach's alpha, whose assumptions are likely to be violated in practice (Yang and Green, 2011), $\lambda 2$ is a more accurate measure of reliability (Guttman, 1945; Sijtsma, 2009).

Customer stressors. The Customer-related Social Stressor scale (CSS) of Dormann and Zapf (2004) in the version used by Dudenhöffer and Dormann (2014드) was applied. This The scale measures four stressors relating to negative customer interactions. The instrument and comprised 15 items, which were slightly adapted into the singular form. Participants had to rate how often they are confronted with disproportionate customer expectations (five items, e.g., "how often do you have contact with customers who do not recognize when you are very busy"); verbally aggressive customers (three items, e.g., "how often do you have contact with customers who personally attack you verbally); disliked customers (three items, e.g., "how often do you have contact with customers who are unpleasant people"); and ambiguous customer expectations (four items, e.g., "how often do you have contact with customers whose requests are not clear"). All $\mathrm{r}$ Responses were made on a five-point seale, ranginged from 1 - "several times an hour" to 5 - "rarely or never" (Johnson et al., 2013). The four 
customer stressors had very good internal consistency with Guttman's lambdas 2 above .80 (see Table 1).

Conflict management. The five Conflict conflict management strategies were measured using a German translation of the Dutch Test of Conflict Handling (De Dreu et al., 2001) by Gross (2004). The scale comprised 20 items (4 items per strategy), which were slightly adapted to customer conflicts_instead of "other party" the word "customer" was $\underline{\text { used). }}$. Participants were asked how often they react by using the following conflict management strategies when being confronted with customer conflicts: avoiding (e.g., "I avoid a confrontation about our differences."), yielding (e.g., "I give in to the wishes of the customer.”), problem solving (e.g., "I examine ideas from both sides to find a mutually optimal solution."), compromising (e.g., "I try to realize a middle-of-the-road solution") and forcing (e.g., "I push my own point of view.”). Responses A five point scale ranginged from 1 - "almost always" to 5 - "never". Internal consistency of the subscales was good (except for compromising): Guttman's lambdas 2 were above .70 in four of five cases. $\underline{\text { Because reliability of compromising was not satisfactory }(\lambda 2<.70) \text { the strategy was excluded }}$ $\underline{\text { from statistical analyses. }}$

Burnout. Burnout was assessed by the German version (Büssing and Glaser, 1998) of the Maslach Burnout Inventory - General Survey (MBI-GS) (Schaufeli et al., 1996) including 16 items on the following three subscales: emotional exhaustion (five items, e.g., "I feel emotionally drained from my work"), cynicism (five items, e.g., "I have become less enthusiastic about my work"), and professional efficacy (six items, e.g., "I have accomplished many worthwhile things in this job.”). All $\mathrm{r}$ Responses were made on a five-point seale, ranginged from 1 - "I totally agree" to 5 - "I totally disagree" (see Johnson et al., 2013; Kim et al., 2007). The three scales had high internal consistency with Guttman's lambdas2 all above .80 (see Table 1$)$. 
Sociodemographic information. Participants were asked to give information on age, gender, work time status (full-/part-time work), job age (years in the current job position), and work age (overall work experience). Scale means, standard deviations, intercorrelations, and Cronbach's alphasGuttman's lambdas 2 are shown in Table 1.

\section{Preliminary Procedure}

Gender, work time status, and job age were considered as covariates and controlled in any analysis. When exploring chronological age in professional contexts, it is essential to differentiate several age conceptualizations related to work, such as work age (overall work experience) and job age (years in a specific job position). As the years in professional life proportionately increase with age, chronological age is strongly correlated with work age (r $=.80$ in the present study, see Table 1). Thus, controlling for work age would lead to a great loss of variance. Therefore, work age was not considered as a covariate. In contrast, controlling for job age is useful because correlation with chronological age is lower $(\mathrm{r}=.58$ in the present study, see Table 1). Since the purpose of the present study is investigating agerelated social expertise in older employees, alternative explanations, such as conflict management skills being a result of short-term behavioral adaptation to the requirements of a specific job position, fairly independent from age, should be ruled out. Thus, it is important to consider job age in the present study. Employee's work time status (full-/part-time work) may impact the frequency of customer stressors and strategy use in customer conflicts, thus is an important control variable as well. Finally, the use of conflict management strategies can be gender-specific (c.f. Holt and DeVore, 2005).Thus, gender was considered as a third covariate. $\underline{\text { All scales were recoded so that high scores indicated high levels of customer }}$ stressors, conflict management, and burnout. 
Table 1

\section{Results}

As stated in Hypothesis 1, there were negative correlations between age and customer stressors (disproportionate expectations $\mathrm{r}=-.14, \mathrm{p}<.01$; verbally aggressive customers $\mathrm{r}=$ $.16, \mathrm{p}<.01$; disliked customers $\mathrm{r}=-.24, \mathrm{p}<.01$; ambiguous expectations $\mathrm{r}=-.27, \mathrm{p}<.01$; see Table 1). Hierarchical regression analysis was conducted to statistically control for covariates. Results suggest that the inclusion of covariates did not reduce but, instead, increased the significant negative correlation between age and each customer stressor (see Table 2). Job age functioned as a suppressor in case of disproportionate expectations, verbally aggressive customers, and disliked customers, since it correlates with age $(r=.58 \mathrm{p}<.01)$, is uncorrelated with those three customer stressors (see Table 1), and mitigates the predictive power of age on customer stressors (Horst et al., 1941). Thus, strong support was found for hypothesis 1 .

Table 2

Hypothesis 2 proposed exposure to customer stressors to mediate between age and emotional exhaustion and cynicism. The bootstrap method was used, which is a recommended procedure for computing indirect effects (Hayes, 2009). The PROCESS macro for SPSS (Hayes, 2013) 
was applied, which computes mediation models statistically controlling for covariates and which-generatesing bias-corrected $95 \%$ bootstrap confidence intervals for indirect effects. Eight mediation models were tested, each with age as the independent variable, customer stressors (4 subscales) as mediators and burnout (emotional exhaustion and cynicism) as outcome variables. For each analysis 10,000 bootstrap samples were used and covariates were controlled for. All eight mediation analyses were significant (see Table 3). Indirect effects of age on emotional exhaustion and cynicism through all four customer stressors were negative and statistically different from zero. This provides strong support for hypothesis 2 .

Table 3

Hypothesis 3a referred to a positive relationship between age and passive avoidant conflict management strategies. Correlational analysis revealed older employees to use more conflict avoidance $(\mathrm{r}=.18, \mathrm{p}<.01$; Table 1$)$. No significant age effect was found for yielding. Hierarchical regression analysis was conducted to statistically control for covariates (see Table 4), which were entered in a first step. Moreover, because we were interested in some further clarification of conflictstrategy use of younger and older employees, independent of their level of customer stressors, we controlled for the stressors expected by taking eustomer stressors into account, which were entered-in a second step. Finally, age was included in a third step to the model. Results show that the inclusion of covariates did not affect the significant positive relation between age and conflict avoidance $(\beta=.17, \mathrm{p}<.01)$, but had an impact on the direction of the age effect on yielding, which changed from positive to negative $(\beta=-.08, \mathrm{p}<.10)$, although slightly failing conventional significance level. 
Surprisingly, job age had a significant positive effect on yielding $(\beta=.18, \mathrm{p}<.01)$. Hypothesis 3a was therefore partly supported.

As stated in Hypothesis 3b, older employees more often used active constructive conflict management strategies, such as eompromising $(\mathrm{r}=.14, \mathrm{p}<.01)$ and problem solving $(\mathrm{r}=.11$, $\mathrm{p}<.05$; Table 1). Again, hierarchical regression analysis was conducted following the same procedure as for Hypotheses $3 \mathrm{a}$ (see Table 4). Results show that controlling for covariates did not affect the significant relationships between age and and problem solving $(\beta=.10, p<.05)$. Job age functioned as a suppressor with regard to eompromising (Horst al., 1941). Hypothesis 3b was therefore supported. The inclusion of customer stressors revealed that when keeping exposure constant, older employees still used conflict management strategies more often than younger employees. There was no hypothesis with regard to the active destructive strategy. Results show no age effect for forcing (see Table 4).

Table 4

Hypothesis 4 proposed older employees would use conflict management strategies more effectively, as indicated by passive avoidant and active constructive strategies leading to lower emotional exhaustion and cynicism, and higher professional efficacy for older employees, compared to younger ones. Moderated regression analyses were conducted, controlling for covariates. As before, exposure to customer stressors was added to each model. Predictors, moderators, and outcome variables were z-standardized (Cohen et al., 
2003). Covariates and customer stressors were entered, followed by predictor and moderator, and then the interaction effect (see Table 5). Seven-Six out of $15 \underline{12}$ interaction effects were significant and revealed a clear pattern.

Professional efficacy. All interaction effects for passive avoidant strategies and for active solvem solving on professional efficacy were significant. Frequent conflict avoidance was associated with significantly more professional efficacy for older but not for younger employees(see Figure 1). Younger employees' professional efficacy was not substantially affected by the frequency of conflict avoidance (see Figure 1). The sameSimilar patterns was found for yielding ${ }^{1}$, out to be beneficial also for younger employees, but not as strongly as for older ones. Forcing revealed no main or interaction effect.

Emotional Exhaustion. Regarding emotional exhaustion, interaction effects for problem solving and forcing were significant. For older employees lower levels of emotional exhaustion occurred when problem solving was a frequent conflict response and higher exhaustion levels when problem solving was an infrequent response. For younger employees there was no such effect and compared to older colleagues, their level of emotional exhaustion was generally higher independent from frequency of strategy use (Figure 1). For avoiding and, yielding, and compromising patterns were similar, but only main effects for age were significant (see Table 5). The opposite is-can be seen for forcing. Older employees rated higher on emotional exhaustion when frequently using this strategy and had lower rates when infrequently using it. Again, for younger compared to older employees generally higher levels of emotional exhaustion occurred, regardless of frequency of strategy use (see Figure 1).

${ }^{1}$ Figures for all interaction effects are available from the first author on request. 
Cynicism. Regarding cynicism, moderated regression revealed a significant interaction only for forcing. Again, for older employees infrequent forcing resulted in lower, and frequent forcing in higher cynicism levels. For younger employees frequency of strategy useforcing did not substantially affect cynicism level. There was a main effect of strategy use for problem solving indicating lower cynicism levels when frequently using this strategy. No interaction or main effects on cynicism were revealed for yielding and avoiding. passive avoidant and active constructive strategies with exception for problem solving with a main effect of strategy use.

Overall, results indicate older employees use passive avoidant and active constructive conflict approaches, such as problem solving, more effectively and benefit more from these compared to younger employees, even when controlling for covariates. For younger employees strategy use did not substantially affect burnout (with the exception of problem solving leading to somewhat higher efficacy and lower cynicism). Also nonsignificant results suggest the tendency of younger employees to show generally higher burnout levels independent from strategy use. Hypothesis 4 was partly supported.

Table 5

\section{Discussion}

Service employees deal with high levels of customer conflicts and require effective conflict management skills in order to meet service job demands. Research on daily hassles (e.g., Blanchard-Fields, 2007; Blanchard-Fields et al., 2007; Diehl et al., 1996) and workplace 
conflict (Davis et al., 2009; Yeung et al., 2015) found that older compared to younger individuals manage conflict more effectively by using passive avoidant and active constructive conflict management strategies. In order to extend $\underline{\text { the research perspective to on }}$ customer conflicts and employee health, this study examined age differences in service employees' perception of customer stressors, in conflict management skills and effectiveness of strategy use in terms of burnout. It was hypothesized, first, that older service employees experience fewer customer stressors and this helps explain lower levels of employee burnout. Second, it was assumed that older employees use more passive avoidant and active constructive conflict management strategies in customer conflicts and they apply those strategies more successfully. Study results show strong support for three of five hypotheses and partial support for two.

As stated in Hypothesis 1, older service employees were less likely to experience customer stressors. This is in line with the study by Johnson et al. (2013). Furthermore, the current study shows that this finding is due to more life experience, but not due to job effects. Job age even masked the effects of age on three of the customer stressors (Horst et al., 1941). An explanation can be that difficult customers may often be assigned to the more experienced and at the same time older employees, who hold the job position for a longer time but when keeping job age constant, older service employees report fewer confrontations with customer stressors. Thus, older service employees experience customer stressors as less negative than younger colleagues.

In line with the results of meta-analyses (e.g., Brewer and Shapard, 2004), older employees were less susceptible to burnout. To explain this finding, the frequency of experienced customer stressors was expected to partially mediate the negative relation between age and emotional exhaustion and cynicism (Hypothesis 2). All indirect effects were significant and revealed older service employees' more positive approach to customer stressors contributes to 
lower levels of exhaustion and cynicism and thus prevents health impairments of negative service interactions. It is, of course, unlikely that customer conflicts are the only explanation for the age-burnout relationship. Therefore, partial rather than full mediation was assumed and confirmed by the data.

On the basis of SST (Carstensen et al., 1999), a positive relation between age and passive avoidant (Hypothesis 3a) and active constructive (Hypothesis 3b) conflict management strategies was expected. Correspondingly, results revealed that older service employees were more likely to avoid customer conflicts compared to younger employees. This is in line with Yeung et al. (2015), who demonstrated older participants of a Chinese sample to use more avoiding when managing conflicts with supervisors. It is interesting that, despite the eulturat differences, the present study replicates the age effect. Individualistic societies, stuch as the present sample, are usually less likely to avoid confliets and approach them by using more active strategies (Friedman et al., 2006). Thus, this finding is noteworthy.Furthermore, it indicates that self-reported strategy use is consistent with ratings made by supervisors, subordinates, and peers in an American sample in Davis et al.'s (2009) study. It is interesting that, despite the cultural differences likely between a Chinese, American, and German sample, the present study replicates the age effects.

With regard to yielding there was a negative relation with age, which slightly failed the conventional significance level. As older people focus more on trustful relationships and positive interactions (Luong et al., 2011), yielding may not be a strategy that is chosen to be often used. Interestingly though ${ }_{2}$ job age was positively related to yielding. One explanation for this is service workers have to manage the conflicting interests of customers and the service organization. Giving in and serving the interests of customers may increase customer satisfaction. Yielding can, for example, mean giving the customer some extra bonus. This is a $\underline{\text { risky strategy, however, because marketing research has shown that customers get all too }}$ 
easily acquainted to all kinds of bonuses (Wilson et al., 2012). Therefore, yielding in order to handle customer conflicts may only be used more often if there is a lot of experience with a particular job, that is, high job age rather than high life experience.

In accordance with Hypothesis $3 b$, older employees reported using more eompromising and problem solving in response to customer conflicts than younger employees. Thisese results persisted even when covariates were taken into account. Thus, as expected and again in line with Davis et al.'s (2099) study, older employees use both passive avoidant, and active constructive conflict strategies, such as problem solving. This suggests that older service employees can draw upon a larger repertoire of conflict skills compared to younger employees due to advanced life experience. This corresponds with existing research showing development and enlargement of conflict management skills with increased age (BlanchardFields et al., 2004 $\div 2007)$.

Hypothesis 4 proposed that older service employees apply conflict management strategies more effectively indicated by high professional efficacy and low emotional exhaustion and cynicism. Passive avoidant and active constructive strategies were assumed to be more helpful with respect to burnout for older than younger employees, whereas the opposite was assumed for forcing. Results show that applying passive avoidant and active constructive strategiesavoiding, yielding, and problem solving were was-linked to higher feelings of professional efficacy for older employees, while younger employees' professional efficacy was mainly independent of these strategies and lower in general. It is important to note that these age differences are highest for frequent use of both passive avoidant strategies. This underpins the assumptions in line with SST and previous research that older workers more effectively minimize social and emotional risks by avoiding conflicts or giving in to the customer in order to regain emotional comfort (Birditt and Fingerman, 2005; Carstensen et al., 1999; Davis et al., 2009; Yeung et al., 2015). Problem solving additionally reduced 
emotional exhaustion for older but not younger employees. Except for forcing, none of the strategies had interaction effects on cynicism. Besides methodological difficulties in detecting moderation effects in general (Cohen et al., 2003; McClelland and Judd, 1993; Moosbrugger et al., 1997), the lack of interaction effects with regard to emotional exhaustion and cynicism can be explained in terms of the job demand resources model (e.g., Schaufeli and Bakker, 2004). Passive avoidant and active constructive conflict management strategies can be described as internal resources for older employees, since these strategies correspond well with their socio-emotionalsocioemotional motivations in social interactions (c.f. Carstensen et al., 1999; Davis et al., 2009). According to the model, resources affect engagement, which involves inter alia efficacy (Maslach and Leiter, 1997), whereas stressors affect the central burnout components emotional exhaustion and cynicism (Schaufeli and Bakker, 2004). Thus, it seems plausible that when older employees solve conflicts frequently by applying passive avoidant and active constructive strategies their feelings of professional efficacy are enhanced, whereas infrequent use of these strategies does not contribute to feeling exhausted or cynical about customers. This notion is further supported and is consistent with our findings for the active destructive conflict strategy (forcing). Here the opposite pattern emerged: there were moderator effects for emotional exhaustion and cynicism, but not for professional efficacy. Theories on conflict management (Thomas, 1992; Van de Vliert, 1997) suggest that each strategy has value under certain conditions. In the service context, where customer orientation is required, forcing seems to be a maladaptive strategy in handling customer conflicts. Moreover, according to SST (Carstensen et al., 1999), it contradicts older employees' social preferences. Therefore, applying forcing is exhausting for older employees and fosters a cynical attitude. Again, for younger service employees the use of forcing did not affect their generally higher levels of emotional exhaustion and cynicism. Overall older service employees are more competent in applying conflict management strategies and benefit 
more from their use, especially when using passive avoidant strategies. It has been shown that the use of passive strategies is more successful in low control situations (Begley, 1998). Service interactions are such low control situations (Zapf, 2002) and the current study can show that passive avoidant conflict management strategies can serve here as an effective behavior in response to customer conflicts, if individual characteristics, such as age, are considered.

It is important to note that, as expected, age effects do not collapse when job age is controlled for. Instead, in some analyses job age even functions as a suppressor and increases relations. Thus, conjecture that effects are merely a result of job effects, which can be learned and compensated at the current job position, can be rejected, and effects can be attributed to agerelated life experience.

In sum, findings are in line with existing literature on age differences in socioemotionalsocioemotional experiences and conflict management revealing that older service employees perceive customer conflicts more positively, experience lower stress due to customers and thus have more resources for managing conflicts successfully, thereby reducing negative health outcomes. Even though the present sample comprises older employees, who do not belong to the population addressed as "older adults" in life span studies, our results are in accordance with life span research and with SST expanding the notion of age-related socio-emotionalsocioemotional advantages to the working context.

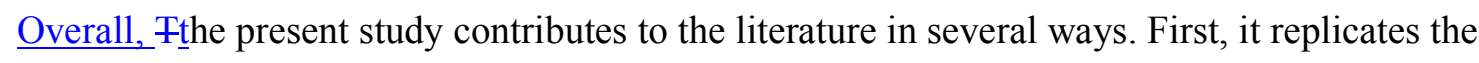
age effect for customer stressors. Second, this study is one of the first that investigates conflict management strategies of workers at different ages in the customer context. In line with previous literature outside the work domain this study shows that older workers are more skilled in using conflict management strategies and that this is due to life rather than job 


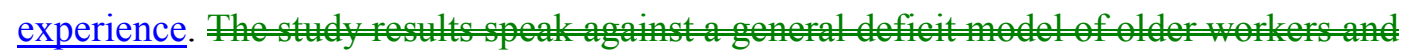
contribute to an model associated with both declines and oains of skills:

\section{Limitations and Future Research}

Although a cross-sectional design can limit study results (Cook et al., 1990), the usual problems of reverse causality cannot apply for chronological age, as long as third variable effects are controlled, as this variable is stable and cannot be affected by other variables (Zapf et al., 1996). That is, experiencing customer stressors or managing conflicts cannot affect the service employee's age. This is different for job age, since the finding that older service employees have advantages in handling customer conflicts could be due to selection effects. Healthy employees could remain in their job position for longer than employees who suffer from health impairments due to high customer stressors and less developed conflict management skills. With regard to competences and health, self-selection effects cannot be discounted in this study. Considering conflict management skills, however, there are numerous studies from a non-working context (e.g., Blanchard-Fields, 2007; Blanchard-Fields et al., 2007; Diehl et al., 1996) showing that these skills can be traced back to advanced life experience. Since job age turned out to play a minor role for our study results, the present findings match well with those of non-working research, so that selection effects cannot fully account for age-related advantages in conflict management. Nevertheless, future research should use longitudinal designs in order to examine age-related conflict behavior over time, to analyze drop out and selection effects, -and to consider the dynamic interplay of conflict behaviors (Trudel and Reio Jr., 2011; Van Jaarsveld et al., 2010). For example, negative customer behaviors could be exhausting and leave no resources in order to handle the situation effectively. In turn, an inappropriate or unfriendly conflict response of the employee 
can provoke further negative behavior of the customer and may lead to further exhaustion (c.f. De Dreu et al., 2004; Trudel and Reio Jr., 2011; Van Jaarsveld et al., 2010).

A second problem of the study is the use of self-report measures. Nonetheless, our results are in line with other research findings, who circumvent self-reports using a multiple rater design (e.g., Davis et al., 2009) and show that supervisors, subordinates, and peers agree that older employees use more frequent passive avoidant and active constructive conflict responses. With regard to chronological age, one can belie assume that participants will know their exact age, and since participation was anonymous, self-reported age should be reliable and should not be affected by typical self-report measure problems leading to common method variance, such as social desirability (Spector, 2006) or negative affect (Spector et al., 2000). Considering customer stressors, older employees were expected to perceive negative customer behaviors more positively. Thus, this assumption was only measurable by self-reports.

However, future research should involve not only the employee's view, but also the customer perspective on the employee's conflict behavior, as well as the customer's conflict approach. all relevant conflict parties in order to address this issue without necessarily making use of onthe job observations, whose implementation may be difficult. This could be realized, by assessing conflict strategies both subjectively and objectively in conflict dyads usingfor example, by conflict management measures aimed at more concrete behavioral aspects than conflict styles, such as the dynamic conflict profile (e.g., Davis et al., 2004). To the best of our knowledge, there exist only behavior ratings without self-report measures (Davis et al., 2009) or solely self-report measures without objective ratings like in Yeung et al.'s (2015) and in the present study. A subjective and objective dyad approach could minimize recall errors in self-reported conflict behavior and would allow more precise measurement of age effects. In this line, the age of the interaction partner could play an important role. Fingerman et al. (2008) have shown that participants used different conflict management strategies 
depending on the interaction partner's age. Therefore, future research should assess conflict $\underline{\text { behavior in dyads of different ages in order to make statements about conflict management }}$ across generations. Moreover, most studies on socioemotional competences stem from nonworking settings. However, the work environment entails different aspects, which may influence and limit the choice of conflict behavior, which were not considered in the present $\underline{\text { study. For example, display rules, which implicitly or explicitly prescribe the organizations }}$ expectation of emotional expression in customer interactions (Grandey, 2003), may impact $\underline{\text { conflict management with customers. Also, leadership and organizational conflict culture }}$ influence conflict behavior in organizations (Gelfand et al., 2012). Thus, organizational environment factors should be considered in future research as well.

Finally, it is important to address the potential influence of cultural characteristics on organizational behavior (Brodbeck et al., 2002) in a German sample. Considering results of the GLOBE (Global Leadership and Organizational Behavior Effectiveness) project, Germany, compared to 61 other countries, ranks very high on sociocultural dimensions such $\underline{\text { as assertiveness, uncertainty avoidance and high on performance orientation (Brodbeck et al., }}$ 2002; Brodbeck and Frese, 2007). Thus, German people are usually confrontational, tough, and straightforward in interpersonal interactions, show high tolerance for dispute and are less $\underline{\text { likely to avoid conflicts (Brodbeck et al., 2002; Friedman et al., 2006). These cultural }}$ $\underline{\text { characteristics may influence the way German service employees handle conflicts with }}$ customers. However, despite the cultural differences between Germany (present study), China (Yeung et al., 2015), and the U.S. (Davis et al., 2009), similar age effects have been found for $\underline{\text { conflict management. Therefore, cultural influences seem not to be dominant in the present }}$ study. Furthermore, comparing mean values for conflict management assessed via the Dutch Test of Conflict Handling across countries (see for example: De Dreu et al., 2001; Rizkalla et al., 2008; Zhang et al., 2014) reveals that means are similar across these cultures with problem 
solving being high and also forcing being quite high relative to the other strategies. The present sample differs from this pattern in that forcing was lowest. This is, however, in line with van Dierendonck and Mevissen's (2002) study with service employees. Thus, a possible explanation is that the present sample shares a typical pattern found in service samples, where forcing is not an adequate strategy in deescalating customer conflicts and thus not often used. $\underline{\text { In conclusion, situational rather than cultural characteristics may play a superior role in }}$ determining the conflict strategies analyzed in this study. With regard to burnout, the correlation pattern of subscales of the present study is in line with the meta-analysis of Lee and Ashforth (1996) and other studies using the General Survey version of the Maslach Burnout Inventory (e.g., Schaufeli et al., 2002) suggesting that there is little cultural idiosyncrasy in the present sample.

$\underline{\text { In sum, the findings of the present study are noteworthy and age effects, especially with }}$ $\underline{\text { regard to the avoidance preference, seem not to be culture-specific. Note, however, that the }}$ number of studies is still limited. More research is required here.

\section{Implications for Practice}

Many industrialized countries have to deal with demographic problems due to a substantial decrease of the younger workforce (e.g., Hertel and Zacher, in press). Though the percentage of employed older workers has increased in most European countries in recent years (Eurostat, 2014), older people still face more problems in finding a job. In Germany, for example, the chance of reemployment for older workers ( $>55$ years) is only about half as $\underline{\text { high as it is for younger workers (Bundesagentur für Arbeit, 2015). While this may have }}$ $\underline{\text { several explanations, one is that there are stereotypes against older workers culminating in a }}$ general 'deficit model' (Hertel and Zacher, in press). Although age-related declines in basic 
$\underline{\text { cognitive skills, such as reaction time, cannot be denied, research has shown that there are }}$ also age-related gains. A neglected field has been the socioemotional skills of older employees. Addressing this research gap, the contribution of the present study is that older $\underline{\text { workers' socioemotional skills are neither worse, nor simply equivalent to those of younger }}$ employees. Rather, in many respects an age-related increase in effective conflict management can be observed. Thus, the The study results speak against a general deficit model of older workers and contribute to an age model associated with both declines and gains of skills. Therefore, organizations would not only be advised to overcome negative prejudices against older employees' competences, but also to build on age-related socioemotional expertise, especially with regard to service jobs. In this regard, Ssuccessful conflict management can contribute to high service quality and customer loyalty (Balay, 2007), and can be beneficial for service employees' wellbeing, and thus for the organization as a whole. Therefore, organizations will benefit from using conflict management training as persennel development tool. Service employees may gain confidence in handling demanding customers and disputes, and can learn to allocate their resources wisely. Since chronological age is not a modifiable variable through training, it seems legitimate to question the significance of age effects with $\underline{\text { regard to practical implications. However, as research on personnel psychology shows, }}$

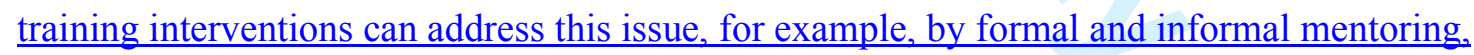
$\underline{\text { which can have mutual benefits for the older mentor and the younger protégé (Eby et al., }}$ 2006). Thus, older service employees' advantages in dealing with negative social interactions, and use of this knowledge in order to support younger colleagues, represent a valuable resource for organizations.

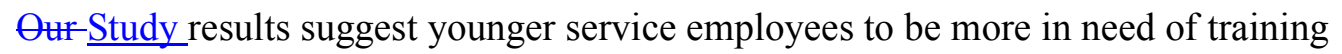
interventions, because they experience more customer stressors, because they do not benefit much from conflict strategy use and generally show high burnout levels. In contrast, older 
service employees' expertise in dealing with negative social interactions represents an important resource. Their knowledge could be used to support younger colleagues, for example in mentoring programs. Moreover, organizations should tailor training interventions to the certain needs and socio-emotional motivations of different ages, and furthermore, should consider the situational restrictions for conflict behaviors in customer interactions. Consequently, organizations should provide training interventions, especially for younger employees, teaching effective conflict approaches and their impact on customers as well as $\underline{\text { situational restrictions which limit strategy use in service interactions. In order to achieve }}$ behavioral changes, it is recommendable to practice strategy application in realistic servicerelated role plays with video feedback interventions on the basis of behavior modeling training (Taylor et al., 2005). Younger employees may gain confidence in handling demanding customers and learn to allocate their resources wisely. Older employees may benefit from such trainings as well by intensifying conflict approaches, which are most helpful to them. With regard to customer stressors, an important aspect of excellent customer $\underline{\text { service is an effective handling of these demanding customer situations, which may require a }}$ change of appraisal. Hence, organizations would be advised to offer stress management $\underline{\text { training (Murphy, 1996) as part of customer service skills training programs in order to reduce }}$ employee burnout (Johnson et al., 2013). Finally, providing employees with resources and addressing the demands they face in service interactions are important aspects of organizational interventions in terms of burnout reduction (Halbesleben and Buckley, 2004). One resource that has been shown to be effective in reducing burnout is supervisor support (Brewer and Shapard, 2004). Supervisors should be trained with regard to their awareness and $\underline{\text { sensitivity to age differences and in proactively providing adequate support to their }}$ subordinates of different ages. As one source of burnout, unrealistic expectations of job demands can be addressed by means of human resource management. For example, realistic 
job previews as part of job interviews can minimize mismatches of expected and subsequent experienced job demands (Halbesleben and Buckley, 2004).

\section{Conclusion}

In sum, this study contributes to a wider understanding of age differences in conflict management and is one of the few to examine conflict management skills in older service employees and with regard to customer conflicts. It shows that existing findings from research on daily conflicts in old age are also valid for older employees, who, in comparison, belong to a younger age group of the population. Thus, age-related development and maturation of conflict management skills seem to occur at an earlier stage, meaning older employees can take advantage of these resources already in professional life. The study shows that older employees are well equipped with socio-emotionalsocioemotional competences and are better well qualified for handling demanding work interactions than younger employees. Overall this challenges prevailing stereotypes and prejudices about older employees' work performance. The study recommends organizations to draw upon this valuable resource of eompetencies, and provide age-differentiated support to employees in terms of their use of conflict management strategies.

\section{Reference List}

Balay, R. (2007), "Predicting conflict management based on organizational commitment and selected demographic variables", Asia Pacific Education Review, Vol 8 No.2, pp. 321336. 
Baltes, P.B. and Smith, J. (2008), “The fascination of wisdom: its nature, ontogeny, and function”, Perspectives on Psychological Science, Vol. 3 No. 1, pp. 56-64.

Baltes, P.B., Staudinger, U.M., Maercker, A. and Smith, J. (1995), "People nominated as wise: a comparative study of wisdom-related knowledge", Psychology and Aging, Vol. 10 No. 2, pp. 155-166.

Barki, H. and Hartwick, J. (2004), "Conceptualizing the construct of interpersonal conflict", International Journal of Conflict Management, Vol. 15 No. 3, pp. 216-244.

Baumeister, R.F., Muraven, M. and Tice, D.M. (2000), "Ego depletion: a resource model of volition, self-regulation, and controlled processing", Social Cognition, Vol. 18 No. 2, pp. $130-150$.

Begley, T.M. (1998), “Coping strategies as predictors of employee distress and turnover after an organizational consolidation: a longitudinal analysis", Journal of Occupational and Organizational Psychology, Vol 71, pp. 305-329.

Ben-Zur, H. and Yagil, D. (2005), “The relationship between empowerment, aggressive behaviours of customers, coping, and burnout", European Journal of Work and Organizational Psychology, Vol. 14 No. 1, pp. 81-99.

Bergstrom, M.J. and Nussbaum, J.F. (1996), “Cohort differences in interpersonal conflict: implications for the older patient - younger care provider interaction”, Health Communication, Vol. 8 No.3, pp. 233-248.

Bitner, M.J., Booms, B.H. and Mohr, L.A. (1994), “Critical service encounters: the employee's viewpoint”, Journal of Marketing, Vol. 58, pp. 95-106. 
Birditt, K.S. (2014), “Age differences in emotional reactions to daily negative social encounters", Journals of Gerontology, Series B: Psychological Sciences and Social Sciences, Vol. 69 No. 4, pp. 557-566.

Birditt, K.S. and Fingerman, K.L. (2005), "Do we get better at picking our battles? Age group differences in descriptions of behavioral reactions to interpersonal tensions", Journal of Gerontology: Psychological Sciences, Vol. 60B No. 3, pp. 121-128.

Birditt, K.S., Fingerman, K.L. and Almeida, D.M. (2005), “Age differences in exposure and reactions to interpersonal tensions: a daily diary study", Psychology and Aging, Vol. 20 No. 2, pp. 330-340.

Blanchard-Fields, F. (2007), "Everyday problem solving and emotion: an adult developmental perspective”, Current Directions in Psychological Science, Vol. 16 No. 1, pp. 26-31.

Blanchard-Fields, F., Jahnke, H.C. and Camp, C. (1995), “Age differences in problem-solving style: the role of emotional salience", Psychology and Aging, Vol. 10 No. 2, pp. 173180.

Blanchard-Fields, F., Mienaltowski, A. and Seay, R.B. (2007), “Age differences in everyday problem-solving effectiveness: older adults select more effective strategies for interpersonal problems", Journal of Gerontology: Psychological Sciences, Vol. 62B No. 1, pp. 61-64.

Blanchard-Fields, F., Stein, R. and Watson, T.L. (2004), “Age differences in emotionregulation strategies in handling everyday problems", Journal of Gerontology: Psychological Sciences, Vol. 59B No. 6, pp. 261-269. 
Bolger, N., DeLongis, A., Kessler, R.C. and Schilling, E.A. (1989), "Effects of daily stress on negative mood", Journal of Personality and Social Psychology, Vol. 57 No. 5, pp. $808-818$.

Brewer, E.W. and Shapard, L. (2004), "Employee burnout: a meta-analysis of the relationship between age or years of experience", Human Resource Development Review, Vol. 3 No. 2, pp. 102-123.

Brodbeck, F.C., Frese, M. and Javidan, M. (2002), "Leadership made in Germany: low on compassion, high on performance", Academy of Management Executive, Vol. 16 No. 1, pp. 16-29.

Brodbeck, F.C. and Frese, M. (2007), "Societal culture and leadership in Germany", in $\underline{\text { Chhokar, J.S., Brodbeck, F.C. and House, R.J. (Eds.), Culture and Leadership Across }}$ the World. The GLOBE Book of In-Depth Studies of 25 Societies, Lawrence Erlbaum Associates, Mahwah, NJ, pp. 147-214.

Büssing, A. and Glaser, J. (1998), “Managerial Stress und Burnout. A Collaborative International Study (CISMS). Die deutsche Untersuchung”, [Managerial stress and burnout. The German study], Bericht Nr. 44 aus dem Lehrstuhl für Psychologie, Technische Universität, Lehrstuhl für Psychologie, München.

Bundesagentur für Arbeit (2015), „Arbeitsmarktberichterstattung. Der Arbeitsmarkt in Deutschland - Ältere am Arbeitsmarkt", Nürnberg, available at: http://statistik.arbeitsagentur.de/Statischer$\underline{\text { Content/Arbeitsmarktberichte/Personengruppen/generische-Publikationen/Aeltere- }}$ amArbeitsmarkt-2014.pdf (accessed 16 January 2016) 
Carstensen, L.L., Isaccowitz, D.M. and Charles, S.T. (1999), “Taking time seriously: a theory of socioemotional selectivity", American Psychologist, Vol. 54 No. 3, pp. 165-181.

Charles, S.T., Mather, M. and Carstensen, L.L. (2003), “Aging and emotional memory: the forgettable nature of negative images for older adults", Journal of Experimental Psychology: General, Vol. 132 No. 2, pp. 310-324.

Charles, S.T., Piazza, J.R., Luong, G. and Almeida, D.M. (2009), "Now you see it, now you don't: age differences in affective reactivity to social tensions", Psychology and Aging, Vol. 24 No. 3, pp. 645-653.

Chen, Y., Ferris, D. L., Kwan, H. K., Yan, M., Zhou, M. and Hong, Y. (2013), “Self-love's lost labor: A self-enhancement model of workplace incivility", Academy of Management Journal, Vol. 56 No. 4, pp. 1199-1219.

Cohen, J., Cohen, P., West, S. and Aiken, L.S. (2003), Applied Multiple Regression/Correlation Analysis for the Behavioral Sciences, 3rd ed., Lawrence Erlbaum Associates, Mahwah, NJ.

Cook, T.D., Campbell, D.T. and Peracchio, L. (1990), “Quasi-experimentation”, in Dunnette, M.D. and Hough, L.M. (Eds.), Handbook of Industrial and Organizational Psychology, Vol. 1, Consulting Psychologists Press, Palo Alto, CA, pp. 491-576.

Dahling, J.J. and Perez, L.A. (2010), “Older worker, different actor? Linking age and emotional labor strategies”, Personality and Individual Differences, Vol. 48, pp. 574578.

Davis, M.H., Capobianco, S. and Kraus, L.A. (2004), "Measuring conflict-related behaviors: reliability and validity evidence regarding the conflict dynamics", Educational and Psychological Measurement, Vol. 64 No. 4, pp. 707-731. 
Davis, M.H., Kraus, L.A. and Capobianco, S. (2009), “Age differences in responses to conflict in the workplace”, The International Journal of Aging and Human Development, Vol. 68 No. 4, pp. 339-355.

De Dreu, C.K.W., Evers, A., Beersma, B., Kluwer, E.S. and Nauta, A. (2001), “A theorybased measure of conflict management strategies in the workplace", Journal of Organizational Behavior, Vol. 22 No. 6, pp. 645-668.

De Dreu, C.K.W., van Dierendonck, D. and Dijkstra, M.T.M. (2004), "Conflict at work and individual well-being”, International Journal of Conflict Management, Vol. 15 No. 1, pp. 6-26.

De Dreu, C. K. W. and van Knippenberg, D. (2005), "The possessive self as a barrier to conflict resolution: effects of mere ownership, process accountability, and self-concept clarity on competitive cognitions and behavior", Journal of Personality and Social Psychology, Vol. 89 No. 3, pp. 345-357.

Diehl, M., Coyle, N. and Labouvie-Vief, G. (1996), “Age and sex differences in strategies of coping and defense across the life span”, Psychology and Aging, Vol. 11 No. 1, pp. 127-139.

Dijkstra, M.T.M., De Dreu, C.K.W., Evers, A. and van Dierendonck, D. (2009), "Passive responses to interpersonal conflict at work amplify employee strain”, European Journal of Work and Organizational Psychology, Vol. 18 No. 4, pp. 405-423.

Dormann, C., and Zapf, D. (2004), “Customer-related social stressors and burnout”, Journal of Occupational Health Psychology, Vol. 9 No. 1, pp. 61-82. 
Dudenhöffer, S. and Dormann, C. (20154), “Customer-related social stressors: meaning and consequences across service jobs" ${ }_{2}$. Manuseript submitted for publication $\underline{\text { Journal of }}$ Personnel Psychology, Vol. 14 No. 4, pp. 165-181.

Eby, L.T., Lockwood, A.L. and Butts, M. (2006), "Perceived support for mentoring: a multiple perspectives approach", Journal of Vocational Behavior, Vol. 68, pp. 267291.

European Commission, (2015), "Single market for services", available at: http://ec.europa.eu/internal_market/top_layer/services/index_en.htm (accessed 01 November 2015).

Eurostat (2014), "Employment rate of older workers", available at: http://epp.eurostat.ec.europa.eu/tgm/table.do?tab=table\&init=1\&plugin=1\&language= $\underline{\text { en } \& \text { pcode }=\text { tsdde100 (accessed } 16 \text { January } 2016)}$

Fingerman, K.L., Miller, L. and Charles, S. (2008), "Saving the best for the last: how adults treat social partners of different ages", Psychology and Aging, Vol. 23 No. 2, pp. 399409.

Friedman, R., Chi, S.C. and Liu, L.A. (2006), “An expectancy model of Chinese - American differences in conflict-avoiding”, Journal of International Business Studies, Vol. 37 No. 1, pp. 76-91.

Gelfand, M.J., Leslie, L.M., Keller, K. and de Dreu, C. (2012), "Conflict cultures in organizations: how leaders shape conflict cultures and their organizational-level consequences“, Journal of Applied Psychology, Vol. 97 No. 6, pp. 1131-1147.

Guttman, L. (1945), “A basis for analyzing test-retest reliability”, Psychometrika, Vol. 10 No. 4, pp. 255-282. 
Grandey, A. (2003), "When "the show must go on": surface and deep acting as predictors of emotional exhaustion and service delivery", Academy of Management Journal, Vol. $\underline{46 \text { No. } 1, \text { pp. } 86-96 .}$

Grandey, A.A., Dickter, D.N. and Sin, H-P. (2004), "The customer is not always right: customer aggression and emotion regulation of service employees", Journal of Organizational Behavior, Vol. 25, pp. 397-418.

Grandey, A.A., Kern, J.H. and Frone, M.R. (2007), "Verbal abuse from outsiders versus insiders: comparing frequency, impact on emotional exhaustion, and the role of emotional labor", Journal of Occupational Health Psychology, Vol. 12 No. 1, pp. 6379.

Grandey, A.A., Tam, A.P. and Brauburger, A.L. (2002), “Affective states and traits in the workplace: diary and survey data from young workers", Motivation and Emotion, Vol. 26 No. 1, pp. 31-55.

Gross, C.T. (2004), “Analyse sozialer Konflikte und Mobbing am Arbeitsplatz - eine Tagebuchstudie (ASKA-Projekt)", [Analysis of social conflict and mobbing at worka daily diary study (ASKA project), Goethe University Frankfurt, unpublished dissertation.

Gross, M.A. and Guerrero, L.K. (2000), "Managing conflict appropriately and effectively: an application of the competence model to Rahim's organizational conflict styles”, International Journal of Conflict Management, Vol. 11 No. 3, pp. 200-226.

Grossmann, I., Na, J., Varnum, M.E.W., Park, D.C., Kitayama, S. and Nisbett, R.E. (2010), "Reasoning about social conflicts improves into old age", Proceedings of the National 
Academy of Sciences of the United States of America (PNAS), Vol. 107 No. 16, pp. 7246-7250.

Gupta, N., Ganster, D.C. and Kepes, S. (2013), “Assessing the validity of sales self-efficacy: a cautionary tale", Journal of Applied Psychology, Vol. 98 No. 4, pp. 690-700.

Halbesleben, J.R.B. and Buckley, M.R. (2004), "Burnout in organizational life”, Journal of Management, Vol. 30 No. 6, pp. 859-879.

Hayes, A.F. (2009), "Beyond Baron and Kenny: Statistical mediation analysis in the new millennium”, Communication Monographs, Vol. 76 No. 4, pp. 408-420.

Hayes, A.F. (2013), Introduction to Mediation, Moderation, and Conditional Process Analysis. A Regression-based Approach, Guilford, New York, NY.

Hertel, G. and Zacher, H. (in press), "Managing the aging workforce", in Viswesvaran, C., Anderson, N., Ones, D.S. and Sinangil, H.K. (Eds.), The SAGE Handbook of $\underline{\text { Industrial, Work, and Organizational Psychology, 2nd ed. Vol. 3, Sage Publications, }}$ London.

Holt, J. L. and DeVore, C. J. (2005), “Culture, gender, organizational role, and styles of conflict resolution: a meta-analysis", International Journal of Intercultural Relations, Vol. 29, pp. 165-196.

Horst, P., Wallin, P., Guttman, L., Wallin, F., Clausen, J. A., Reed, R. and Rosenthal, E. (1941), The Prediction of Personal Adjustment: A Survey of Logical Problems and Research Techniques, with Illustrative Application to Problems of Vocational Selection, School Success, Marriage, and Crime, Social Science Research Council, New York. 
Johnson, S J., Holdsworth, L., Hoel, H. and Zapf, D. (2013), “Customer stressors in service organizations: the impact of age on stress management and burnout", European Journal of Work and Organizational Psychology, Vol. 22 No. 3, pp. 318-330.

Kern, J.H. and Grandey, A.A. (2009), "Customer incivility as a social stresser: The role of race and racial identity for service employees", Jom nal of Ocention Health Psychology, Vol. 14 No. 1, pp. 4657.

Kim, H.J., Shin, K.H. and Umbreit, W.T. (2007), "Hotel job burnout: The role of personality characteristics", International Journal of Hospitality Management, Vol. 26, pp. 421434.

Lee, R.T and Ashforth, B.E (1996), “A meta-analytic examination of the correlates of the three dimensions of job burnout", Journal of Applied Psychology, Vol. 81 No. 2, pp. $\underline{123-133 .}$

Little, R.J.A. and Rubin, D.B. (2002), Statistical Analysis with Missing Data, 2nd ed., Wiley \& Sons, New York.

Luong, G., Charles, S.T. and Fingerman, K.L. (2011), "Better with age: social relationships across adulthood”, Journal of Social and Personal Relationships, Vol. 28, pp. 9-23.

Maslach, C. and Leiter, M.P. (1997), The Truth about Burnout: How Organizations cause Personal Stress and what to do about it, Jossey-Bass, San Francisco, CA.

McClelland, G.H. and Judd, C.M. (1993), "Statistical difficulties of detecting interactions and moderator effects", Psychological Bulletin, Vol. 114 No. 2, pp. 376-390. 
Moosbrugger, H., Schermelleh-Engel, K. and Klein, A. (1997), "Methodological problems of estimating latent interaction effects", Methods of Psychological Research Online, Vol. 2 No. 2 , pp. $95-111$.

Ng, T.W.H. and Feldman, D.C. (2010), "The relationships of age with job attitudes: a metaanalysis", Personnel Psychology, Vol. 63, pp. 677-718.

Nguyen, H.H.D. and Yang, J. (2012), “Chinese employees’ interpersonal conflict management strategies", International Journal of Conflict Management, Vol. 23 No. 4, pp. 382-412.

Murphy, L.R. (1996), "Stress management in work settings: a critical review of the health effects", American Journal of Health Promotion, Vol. 11 No. 2, pp. 112-135.

Pruitt, D.G. and Rubin, J.Z. (1986), Social Conflict: Escalation, Stalemate and Settlement, Random House, New York, NY.

Rizkalla, L., Wertheim, E.H. and Hodgson, L.K. (2008), “The roles of emotion management and perspective taking in individuals' conflict management styles and disposition to forgive", Journal of Research in Personality, Vol. 42, pp. 1594-1601.

Schaufeli, W.B. and Bakker, A.B. (2004), “Job demands, job resources, and their relationship with burnout and engagement: a multi-sample study", Journal of Organizational Behavior, Vol. 25, pp. 293-315.

Schaufeli, W.B., Leiter, M.P., Maslach, C. and Jackson, S.E. (1996), “Maslach Burnout Inventory-General Survey (MBI-GS)", in Maslach, C., Jackson, S. E. and Leiter, M. P. (Eds.), Maslach Burnout Inventory Manual, 3rd ed., Consulting Psychologists Press, Palo Alto, CA, pp. 22-26. 
Schaufeli, W.B., Salanova, M., González-Romá, V. and Bakker, A. (2002), “The

measurement of engagement and burnout: a two sample confirmatory factor analytic approach", Journal of Happiness Studies, Vol. 3, pp. 71-92.

$\underline{\text { Schmidt, K.H., Neubach, B. and Heuer, H. (2007), "Self-control demands, cognitive control }}$ deficits, and burnout", Work and Stress, Vol. 21 No. 2, pp. 142-154.

Shin, H., Park, Y.M., Ying, J.Y., Kim, B., Noh, H. and Lee, S.M. (2014), “Relationships between coping strategies and burnout symptoms: a meta-analytic approach", Professional Psychology: Research and Practice, Vol. 45 No. 1, pp. 44-56.

Sijtsma, K. (2009), "On the use, the misuse, and the very limited usefulness of Cronbach's alpha", Psychometrika, Vol. 74 No. 1, pp. 107-120.

Sitzmann, T. and Yeo, G. (2013), "A meta-analytic investigation of the within-person selfefficacy domain: is self-efficacy a product of past performance or a driver of future performance?”, Personnel Psychology, Vol. 66, pp. 531-568.

Spector, P.E. (2006), “Method variance in organizational research: truth or urban legend?”, Organizational Research Methods, Vol. 9 No. 2, pp. 221-232.

Spector, P.E., Zapf, D., Chen, P.Y., and Frese, M. (2000), "Why negative affectivity should not be controlled in job stress research: don't throw out the baby with the bath water", Journal of Organizational Behavior, Vol. 21, pp. 79-95.

Stajkovic, A.D. and Luthans, F. (1998), "Self-efficacy and work-related performance: a metaanalysis", Psychological Bulletin, Vol. 124 No. 2, pp. 240-261. 
Taylor, M.T. and Moghaddam, F.M. (1994), Theories of Intergroup Relations: International Social Psychological Perspectives, Praeger publishers/Greenwood Publishing Group Inc, Westport, CT.

Taylor, P.J., Russ-Eft, D.F. and Chan, D.W.L. (2005), “A meta-analytic review of behavior modeling training", Journal of Applied Psychology, Vol. 90 No. 4, pp. 692-709.

Thomas, K.W. (1992), “Conflict and negotiation processes in organizations”, in Dunnette, M.D. and Hough, L.M. (Eds.), Handbook of Industrial and Organizational Psychology, 2nd ed., Rand McNally, Chicago, pp. 651-717.

Trudel, J. and Reio Jr., T.G. (2011), "Managing workplace incivility: the role of conflict management styles —antecedent or antidote?" Human Resource Development Quarterly, Vol. 22 No. 4, pp. 395-423.

Van de Vliert, E. (1997), Complex Interpersonal Conflict Behavior: Theoretical Frontiers, Psychology Press, Hove.

Van Dierendonck, D. and Mevissen, N. (2002), “Aggressive behavior of passengers, conflict management behavior, and burnout among trolley car drivers", International Journal of Stress Management, Vol 9 No. 4, pp. 345-355.

Van Jaarsveld, D.D., Walker, D.D. and Skarlicki, D.P. (2010), “The role of job demands and emotional exhaustion in the relationship between customer and employee incivility", Journal of Management, Vol. 36 No. 6, pp. 1486-1504.

Watson, T.L. and Blanchard-Fields, F. (1998), "Thinking with your head and your heart: age differences in everyday problem-solving strategy preferences”, Aging, Neuropsychology, and Cognition, Vol. 5 No. 3, pp. 225-240. 
Wilson, A., Zeithaml, V. A., Bitner, M. J. and Gremler, D. D. (2012), Services Marketing: Integrating Customer Focus Across the Firm, 2nd Ed, McGraw-Hill, New York, NY. Yang, Y. and Green, S.B. (2011), "Coefficient alpha: a reliability coefficient for the 21st century?" Journal of Psychoeducational Assessment, Vol 29 No. 4, pp. 377-392.

Yeung, D.Y. and Fung, H.H. (2012), "Impacts of suppression on emotional responses and performance outcomes: an experience-sampling study in younger and older workers”, The Journals of Gerontology, Series B: Psychological Sciences and Social Sciences, Vol. 67 No.6, pp. 66-676.

Yeung, D.Y., Fung, H.H. and Chan, D. (2015), "Managing conflict at work: comparison between younger and older managerial employees", International Journal of Conflict Management, Vol. 26 No. 3, pp. 342-364.

Zhang, Q., Ting-Toomey, S. and Oetzel, J.G. (2014), "Linking emotion to the conflict facenegotiation theory: a U.S.-China investigation of the mediating effects of anger, compassion, and guilt in interpersonal conflict", Human Communication Research Vol. 40, pp. 373-395.

Zapf, D. (2002), "Emotion work and psychological well-being: a review of the literature and some conceptual considerations", Human Resource Management Review, Vol. 12, pp. 237-268.

Zapf, D., Dormann, C. and Frese, M. (1996), "Longitudinal studies in organizational stress research: a review of the literature with reference to methodological issues", Journal of Occupational Health Psychology, Vol. 1 No. 2, pp. 145-169. 
1

2

3

4

5

6

7

8

9

10

11

12

13

14

15

16

17

18

19

20

21

22

23

24

25

26

27

28

29

30

31

32

33

34

35

36

37

38

39

40

41

42

43

44

45

46

47

48

49

50

51

52

53

54

55

56

57

58

59

60
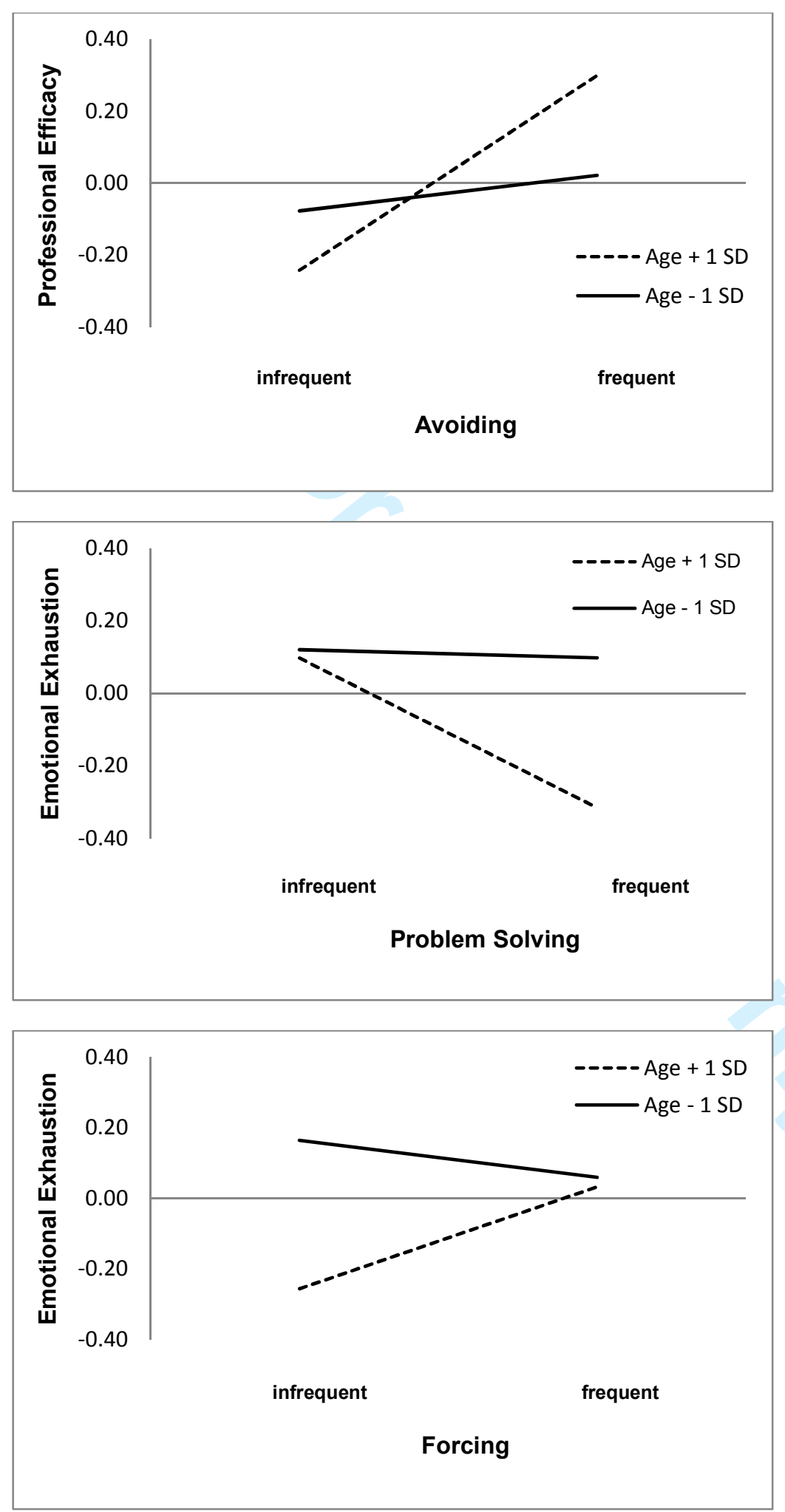

Figure 1. Interactions of age and conflict management on burnout. SD = Standard deviation. 
1

\section{CONFLICT MANAGEMENT AND AGE}

Table 1

Mean Values, Standard Deviations, and Intercorrelations of Study Variables 10 11 Variable

12 1. Age

13 2. Work age

14 3. Job age

16

17

18

4. Full/part-time work

5. Gender

6. Disproportionate expectations

7. Verbally aggressive customers

8. Disliked customers

9. Ambiguous expectations

10. Yielding

11. Compromising

12. Forcing

13. Problem solving

14. Avoiding

15. Emotional exhaustion

16. Cynicism

17. Professional efficacy

$\begin{array}{cccccc}\boldsymbol{M} & \boldsymbol{S D} & \mathbf{1} & \mathbf{2} & \mathbf{3} & \mathbf{4} \\ 40.63 & 12.17 & - & & & \\ 17.80 & 11.90 & .80^{* *} & - & & \\ 8.95 & 8.58 & .58^{* *} & .64 * * & - & \\ 1.62 & .97 & -.02 & -.05 & .06 & - \\ 1.38 & .49 & .03 & .03 & .01 & -.26 \\ 2.84 & .91 & -.14 * * & -.16^{* *} & .02 & .05 \\ 1.40 & .71 & -.16^{* *} & -.13^{* *} & -.05 & .08 \\ 1.94 & .89 & -.24 * * & -.22^{* *} & -.08 & .14 \\ 2.00 & .83 & -.27 * * & -.26^{* *} & -.13 * * & .10 \\ 3.62 & .67 & .04 & .06 & .15 * * & .10 * \\ 3.45 & .69 & .14 * * & .11^{*} & .06 & -.05 \\ 2.51 & .80 & -.01 & -.01 & -.03 & -.07 \\ 3.92 & .70 & .11^{*} & .11 * & .04 & -.08 \\ 3.58 & .79 & .18^{* *} & .17 * * & .14 * * & .12 \\ 2.49 & .86 & -.20^{* *} & -.12^{* *} & -.10^{*} & -.05 \\ 1.79 & .81 & -.12^{*} & -.08 & -.07 & -.02 \\ 4.12 & .55 & .13 * * & .12^{* *} & .10^{*} & .02\end{array}$

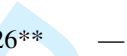

$\begin{array}{lll}.05 & -.03 & .84\end{array}$

$\begin{array}{llll}.08 & .03 & .44 * * & .87\end{array}$

\begin{tabular}{lllll}
\hline$* *$ & .09 & $.50 * *$ & $.66 * *$ & .89
\end{tabular}

$\begin{array}{llllll}10 * & .05 & .53 * * & .59 * * & .74 * * & .88\end{array}$

$\begin{array}{lllllll}.10 * & -.18 * * & .10 * & -.04 & -.07 & -.06 & .73\end{array}$

$\begin{array}{llllllll}-05 & -.05 & .13 * * & .08 & -.02 & .01 & .27 * * & .64\end{array}$

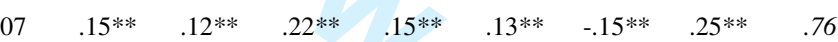

$\begin{array}{llllllllll}. .08 & -.09 * & .06 & -.10 * & -.18 * * & -.14 * * & .39 * * & .58 * * & .09 & .76\end{array}$

$\begin{array}{llllllllllll}.12 * & -.13 * * & .08 & -.01 & -.03 & -.04 & .54 * * & .39 * * & .02 & .35 * * & .71\end{array}$

$\begin{array}{llllllllllll}.05 & .05 & .22 * * & .37 * * & .35 * * & .32 * * & -.09 & -.04 & .13 * * & -.15 * * & -.06 & .87\end{array}$

$\begin{array}{rllllllllllll}. .02 & .09 & .12 * & .36 * * & .36 * * & .36 * * & -.10 * & -.01 & .21 * * & -.23 * * & -.05 & .62 * * & .87\end{array}$

$\begin{array}{llllllllllllll}.02 & -.05 & -.04 & -.14^{* *} & -.17^{* *} & -.16^{* *} & .20^{* *} & .24 * * & -.01 & .41^{* *} & .18^{* *} & -.31^{* *} & -.40^{* *} & .82\end{array}$ 


\section{Page 49 of 53}

\section{CONFLICT MANAGEMENT AND AGE}

Table 2

Regression Results for Customer Stressors and Age (Hypothesis 1)

\begin{tabular}{|c|c|c|c|c|c|c|c|c|}
\hline \multirow[b]{2}{*}{ Variable } & \multicolumn{2}{|c|}{$\begin{array}{c}\text { Disproportionate } \\
\text { customer } \\
\text { expectations }\end{array}$} & \multicolumn{2}{|c|}{$\begin{array}{c}\text { Verbally } \\
\text { aggressive } \\
\text { customer }\end{array}$} & \multicolumn{2}{|c|}{$\begin{array}{c}\text { Disliked } \\
\text { customers }\end{array}$} & \multicolumn{2}{|c|}{$\begin{array}{c}\text { Ambiguous } \\
\text { customer } \\
\text { expectations }\end{array}$} \\
\hline & I & II & I & II & I & II & I & II \\
\hline Job age & .02 & $.15^{* *}$ & -.06 & .05 & $-.10 * *$ & .06 & $-.14 * *$ & .03 \\
\hline Full/part-time work & .04 & .03 & $.09 *$ & $.08^{*}$ & $.18^{* *}$ & $.17 * *$ & $.13 * *$ & $.11 * *$ \\
\hline Gender & -.02 & -.02 & .06 & .06 & $.14 * *$ & $.14 * *$ & $.09^{*}$ & $.09 *$ \\
\hline Age & & $-.23 * *$ & & $-.19 * *$ & & $-.28 * *$ & & $-.28 * *$ \\
\hline $\mathrm{R}^{2}$ & .00 & .04 & .01 & .04 & .05 & .10 & .03 & .09 \\
\hline $\mathrm{R}^{2}$ change & .00 & $.03 * *$ & .01 & $.02 * *$ & $.05 * *$ & $.05 * *$ & $.03 * *$ & $.05 * *$ \\
\hline
\end{tabular}

Note. Entries are standardized regression coefficients. $\mathrm{N}=444$. Gender: $1=$ female, $2=$ male. Working hours: $1=$ full time, $2=$ part-time. $* \mathrm{p}<.05 . * * \mathrm{p}<.01$ 


\section{CONFLICT MANAGEMENT AND AGE}

Table 3

Model Coefficients and Bootstrap Results for Customer Stressors as a Mediator between Age and Burnout (Hypothesis 2)

\begin{tabular}{|c|c|c|c|c|c|c|c|c|c|c|c|c|}
\hline \multirow[b]{3}{*}{ Customer Stressors } & \multicolumn{6}{|c|}{ Emotional Exhaustion } & \multicolumn{6}{|c|}{ Cynicism } \\
\hline & \multicolumn{4}{|c|}{ Regression (B unstandardized) } & \multicolumn{2}{|c|}{$\begin{array}{c}95 \% \text { Bootstrap } \\
\text { confidence interval for ab }\end{array}$} & \multicolumn{4}{|c|}{ Regression (B unstandardized) } & \multicolumn{2}{|c|}{$\begin{array}{l}\text { 95\% Bootstrap confidenc } \\
\text { interval for ab }\end{array}$} \\
\hline & a & B & $c^{\prime}$ & $a b$ & LLCI & ULCI & a & $\mathrm{b}$ & $c^{\prime}$ & $\mathrm{ab}$ & LLCI & ULCI \\
\hline Disproportionate expectations & $-.02 * *$ & $.19 * *$ & $-.01 * *$ & -0.0032 & -0.0062 & -0.0012 & $-.02 * *$ & $.10^{*}$ & -.01 & -0.0016 & -0.0041 & -0.0002 \\
\hline Verbally aggressive customers & $-.01 * *$ & $.42 * *$ & $-.01 *$ & -0.0047 & -0.0079 & -0.0021 & $-.01 * *$ & $.40 * *$ & .00 & -0.0045 & -0.0081 & -0.0018 \\
\hline Disliked customers & $-.02 * *$ & $.32 * *$ & $-.01 *$ & -0.0065 & -0.0101 & -0.0037 & $-.02 * *$ & $.33 * *$ & .00 & -0.0065 & -0.0106 & -0.0037 \\
\hline Ambiguous expectations & $-.02 * *$ & $.30 * *$ & $-.01 *$ & -0.0059 & -0.0094 & -0.0033 & $-.02 * *$ & $.34 * *$ & .00 & -0.0066 & -0.0107 & -0.0037 \\
\hline
\end{tabular}

Note. $\mathrm{a}=$ pathway from independent variable (Age) to mediator (Customer Stressor); $\mathrm{b}=$ pathway from mediator (Customer Stressor) to dependent variable (Burnout);

$c^{\prime}=$ direct effect; $\mathrm{ab}=$ indirect effect. $\mathrm{LL}=$ lower limit; $\mathrm{CI}=$ confidence interval; $\mathrm{UL}=$ upper limit

$\mathrm{N}=444$. Bootstrap sample size $=10,000$

$* \mathrm{p}<.05 . * * \mathrm{p}<.01$. 


\section{CONFLICT MANAGEMENT AND AGE}

Table 4

Regression Results for Age and Conflict Management (Hypothesis 3)

\begin{tabular}{|c|c|c|c|c|c|c|c|c|c|c|c|c|}
\hline \multirow[b]{2}{*}{ Variable } & \multicolumn{3}{|c|}{ Avoiding } & \multicolumn{3}{|c|}{ Yielding } & \multicolumn{3}{|c|}{ Problem Solving } & \multicolumn{3}{|c|}{ Forcing } \\
\hline & $\mathrm{I}$ & II & III & $\mathrm{I}$ & II & III & $\mathrm{I}$ & II & III & $\mathrm{I}$ & II & III \\
\hline Job age & $.14 *$ & $.12 * *$ & .03 & $.15 * *$ & $.13 * *$ & $.18 * *$ & .05 & .02 & -.04 & -.03 & -.02 & -.05 \\
\hline Full/part-time work & $.08 *$ & $.09 *$ & $.10^{*}$ & .05 & .06 & .06 & $-.11 * *$ & -.08 & -.08 & -.03 & -.05 & -.05 \\
\hline Gender & $-.11 *$ & $-.09 *$ & $-.10^{*}$ & $-.17 * *$ & $-.15^{* *}$ & $-.14 * *$ & $-.12 * *$ & $-.09 *$ & $-.09^{*}$ & $.15^{* *}$ & $.14^{* *}$ & $.14 * *$ \\
\hline $\begin{array}{l}\text { Disproportionate } \\
\text { expectations }\end{array}$ & & $.12 *$ & $.13 * *$ & & $.17^{* *}$ & $.17 * *$ & & $.21 * *$ & $.21 * *$ & & .06 & .06 \\
\hline $\begin{array}{l}\text { Verbally aggressive } \\
\text { customers }\end{array}$ & & .00 & -.01 & & -.02 & -.02 & & .00 & -.01 & & $.22 * *$ & $.22 * *$ \\
\hline Disliked customers & & -.03 & -.02 & & -.09 & -.10 & & $-.18 * *$ & $-.17 * *$ & & -.02 & -.01 \\
\hline $\begin{array}{l}\text { Ambiguous } \\
\text { expectations }\end{array}$ & & -.07 & -.05 & & -.06 & -.07 & & -.10 & -.09 & & -.02 & -.02 \\
\hline Age & & & $.17 * *$ & & & -.08 & & & $.10^{*}$ & & & .05 \\
\hline $\mathrm{R}^{2}$ & .04 & .05 & .07 & .06 & .08 & .09 & .02 & .07 & .08 & .03 & .08 & .08 \\
\hline $\mathrm{R}^{2}$ change & $.04 * *$ & .01 & $.02 * *$ & $.06^{* *}$ & $.02 *$ & .00 & $.02 *$ & $.05^{* *}$ & .01 & $.03 * *$ & $.05^{* *}$ & .00 \\
\hline
\end{tabular}

Note. Entries are standardized regression coefficients. $\mathrm{N}=444$. Gender: $1=$ female, $2=$ male. Working hours: $1=$ full time, $2=$ part-time. $* \mathrm{p}<.05 . * * \mathrm{p}<.01$ 


\section{CONFLICT MANAGEMENT AND AGE}

Table 5

Moderated Regression Results for Conflict Management Strategies and Age on Burnout (Hypothesis 4)

\begin{tabular}{|c|c|c|c|c|c|c|c|c|c|}
\hline \multirow[b]{2}{*}{ Variable } & \multicolumn{3}{|c|}{ Emotional exhaustion } & \multicolumn{3}{|c|}{ Cynicism } & \multicolumn{3}{|c|}{ Professional efficacy } \\
\hline & I & II & III & I & II & III & I & II & III \\
\hline \multicolumn{10}{|l|}{ Avoiding } \\
\hline Job age & -.06 & .00 & .00 & -.01 & -.01 & -.01 & .07 & .03 & .03 \\
\hline Full/part-time work & $-.09 *$ & $-.09 *$ & $-.08 *$ & -.06 & -.06 & -.06 & .03 & .02 & .01 \\
\hline Gender & .00 & .00 & .00 & .04 & .04 & .04 & -.02 & -.01 & -.01 \\
\hline Disproportionate expectations & .02 & .01 & .01 & $-.15 * *$ & $-.15 * *$ & $-.15^{* *}$ & .08 & .06 & .06 \\
\hline Verbally aggressive customers & $.23 * *$ & $.23 * *$ & $.23 * *$ & $.22 * *$ & $.22 * *$ & $.22 * *$ & -.05 & -.06 & -.06 \\
\hline Disliked customers & $.14^{*}$ & $.13^{*}$ & $.13^{*}$ & $.14^{*}$ & $.14^{*}$ & $.14 *$ & -.10 & -.09 & -.08 \\
\hline Ambiguous expectations & .07 & .06 & .05 & $.20 * *$ & $.20 * *$ & $.20 * *$ & -.09 & -.08 & -.07 \\
\hline Avoiding & & -.02 & -.02 & & -.01 & -.01 & & $.15 * *$ & $.16^{* *}$ \\
\hline Age & & $-.11 *$ & $-.11 *$ & & -.01 & -.01 & & .04 & .03 \\
\hline Avoiding $\mathrm{x}$ age & & & -.06 & & & -.02 & & & $.11^{* *}$ \\
\hline $\mathrm{R}^{2}$ & .17 & .18 & .18 & .19 & .19 & .19 & .04 & .07 & .08 \\
\hline $\mathrm{R}^{2}$ change & $.17 * *$ & .01 & .00 & $.19 * *$ & .00 & .00 & $.04 * *$ & $.02 * *$ & $.01 *$ \\
\hline \multicolumn{10}{|l|}{ Yielding } \\
\hline Job age & -.06 & .01 & .02 & -.01 & .00 & .00 & .07 & .00 & .00 \\
\hline Full/part-time work & $-.09 *$ & $-.09 *$ & $-.08 *$ & -.06 & -.06 & -.06 & .03 & .02 & .01 \\
\hline Gender & .00 & .00 & -.01 & .04 & .03 & .03 & -.02 & .00 & .00 \\
\hline Disproportionate expectations & .02 & .02 & .02 & $-.15 * *$ & $-.15^{* *}$ & $-.15^{* *}$ & .08 & .05 & .05 \\
\hline Verbally aggressive customers & $.23 * *$ & $.23^{* *}$ & $.24 * *$ & $.22 * *$ & $.22 * *$ & $.21 * *$ & -.05 & -.05 & -.07 \\
\hline Disliked customers & $.14^{*}$ & $.13^{*}$ & $.13^{*}$ & $.14 *$ & $.14^{*}$ & $.14 *$ & -.10 & -.07 & -.07 \\
\hline Ambiguous expectations & .07 & .05 & .04 & $.20 * *$ & $.20 * *$ & $.20 * *$ & -.09 & -.07 & -.05 \\
\hline Yielding & & -.06 & -.06 & & -.04 & -.04 & & $.17 * *$ & $.18^{* *}$ \\
\hline Age & & $-.12 *$ & $-.12 *$ & & -.01 & -.01 & & .08 & .08 \\
\hline Yielding $\mathrm{x}$ age & & & -.06 & & & .01 & & & $.10 *$ \\
\hline $\mathrm{R}^{2}$ & .17 & .18 & .19 & .19 & .19 & .19 & .04 & .08 & .09 \\
\hline $\mathrm{R}^{2}$ change & $.17 * *$ & $.01 *$ & .00 & $.19 * *$ & .00 & .00 & $.04 * *$ & $.03 * *$ & $.01 *$ \\
\hline \multicolumn{10}{|l|}{ Problem solving } \\
\hline Job age & -.06 & .00 & .00 & -.01 & -.02 & -.02 & .07 & .05 & .05 \\
\hline Full/part-time work & $-.09 *$ & $-.10 *$ & $-.08 *$ & -.06 & $-.07 *$ & -.07 & .03 & .06 & .03 \\
\hline Gender & .00 & .00 & -.01 & .04 & .02 & .02 & -.02 & .01 & .01 \\
\hline Disproportionate expectations & .02 & .03 & .03 & $-.15 * *$ & $-.12 * *$ & $-.12 *$ & .08 & .00 & -.01 \\
\hline Verbally aggressive customers & $.23 * *$ & $.23 * *$ & $.24 * *$ & $.22 * *$ & $.22 * *$ & $.22 * *$ & -.05 & -.05 & -.08 \\
\hline Disliked customers & $.14^{*}$ & .12 & .10 & $.14 *$ & $.11^{*}$ & .12 & -.10 & -.02 & .01 \\
\hline Ambiguous expectations & .07 & .05 & .04 & $.20 * *$ & $.19 * *$ & $.19^{* *}$ & -.09 & -.05 & -.04 \\
\hline Problem solving & & $-.10 * *$ & $-.11 * *$ & & $-.16 * *$ & $-.16^{* *}$ & & $.40 * *$ & $.41 * *$ \\
\hline Age & & $-.10 *$ & $-.11 *$ & & .01 & .01 & & .02 & .03 \\
\hline Problem solving $\mathrm{x}$ age & & & $-.10 *$ & & & .00 & & & $.16^{* *}$ \\
\hline $\mathrm{R}^{2}$ & .17 & .19 & .20 & .19 & .21 & .21 & .04 & .19 & .22 \\
\hline $\mathrm{R}^{2}$ change & $.17 * *$ & $.02 * *$ & $.01 *$ & $.19^{* *}$ & $.02 * *$ & .00 & $.04 * *$ & $.15 * *$ & $.02 * *$ \\
\hline
\end{tabular}




\section{CONFLICT MANAGEMENT AND AGE}

1

2

3

4

5

6

7

8

9

10

11

12

13

14

15

16

17

18

19

20

21

22

23

24

25

26

27

28

29

30

31

32

33

34

35

36

37

38

39

40

41

42

43

44

45

46

47

48

49

50

51

52

53

54

55

56

57

58

59

60

Table 5 (continued)

Moderated Regression Results for Conflict Management Strategies and Age on Burnout (Hypothesis 4)

\begin{tabular}{|c|c|c|c|c|c|c|c|c|c|}
\hline \multirow[b]{2}{*}{ Variable } & \multicolumn{3}{|c|}{ Emotional exhaustion } & \multicolumn{3}{|c|}{ Cynicism } & \multicolumn{3}{|c|}{ Professional efficacy } \\
\hline & $\mathrm{I}$ & II & III & $\mathrm{I}$ & II & III & $\mathrm{I}$ & II & III \\
\hline \multicolumn{10}{|l|}{ Forcing } \\
\hline Job age & -.06 & .00 & .00 & -.01 & .00 & -.01 & .07 & .04 & .04 \\
\hline Full/part-time work & $-.09 *$ & $-.09 *$ & $-.08 *$ & -.06 & -.05 & -.05 & .03 & .03 & .03 \\
\hline Gender & .00 & .00 & .00 & .04 & .02 & .02 & -.02 & -.03 & -.03 \\
\hline Disproportionate expectations & .02 & .01 & .01 & $-.15^{* *}$ & $-.16^{* *}$ & $-.16^{* *}$ & .08 & .08 & .08 \\
\hline Verbally aggressive customers & $.23^{* *}$ & $.22 * *$ & $.23^{* *}$ & $.22 * *$ & $.19 * *$ & $.20 * *$ & -.05 & -.06 & -.06 \\
\hline Disliked customers & $.14 *$ & $.13^{*}$ & $.13 *$ & $.14 *$ & $.14 *$ & $.14^{*}$ & -.10 & -.09 & -.09 \\
\hline Ambiguous expectations & .07 & .06 & .05 & $.20^{* *}$ & $.21^{* *}$ & $.20 * *$ & -.09 & -.08 & -.09 \\
\hline Forcing & & .05 & .05 & & $.14 * *$ & $.14 * *$ & & .02 & .02 \\
\hline Age & & $-.12 *$ & $-.11 *$ & & -.02 & -.01 & & .06 & .06 \\
\hline Forcing $\mathrm{x}$ age & & & $.10^{*}$ & & & $.08^{*}$ & & & .01 \\
\hline $\mathrm{R}^{2}$ & .17 & .18 & .19 & .19 & .21 & .21 & .04 & .05 & .05 \\
\hline $\mathrm{R}^{2}$ change & $.17^{* *}$ & .01 & $.01 *$ & $.19 * *$ & $.02 * *$ & .01 & $.04 * *$ & .00 & .00 \\
\hline
\end{tabular}

